\title{
HUMAN RIGHTS LITERACIES AND STUDENTS' PARADOXICAL UNDERSTANDINGS OF TOLERANCE AND RESPECT
}

\author{
C. Roux \\ Department of Curriculum Studies \\ Faculty of Education \\ Stellenbosch University \\ e-mail: cdr@sun.ac.za
}

\section{ABSTRACT}

Ivanhoe $(2009,312)$ states that the 'majority of contemporary Western philosophers who accept the fact of ethical pluralism and take this as a cause for concern, tend to argue for tolerance in the face of such differences'. He further argues that tolerance is mostly understood as the 'uncritical acceptance of a range of competing and mutually irreconcilable values or forms of life'. During the past two years, students at South African public Higher Education Institutions (HEI) were raising more distinct voices about the underlying social issues and economic disparities experienced at these institutions. Many of the students' \#MustFall protests, starting in 2015, have played out on campuses of South Africa's universities. Protesters have been critical of HEl's involvement (especially management) and argue that they did not go far enough to respond to the concerns of students' grievances and demands. Management did not reflect or indicate the urgency to meet or improve their needs on social issues prevalent to higher education communities. Two incidents portrayed in the visual media during the \#FeesMustFall protests, (September and October 2016) at two different universities, showed the complexities of being tolerated or respected. These incidents triggered to review captured data of a funded research project (2012-2015:2018) on human rights literacies. The data collected in this project derived from South African (2013) and both South Africa and international (2015) students' understanding of human rights literacies. The survey and interviews also focussed, inter alia on students' understanding of respect and tolerance as a human right. This article reflects on the complexities underlying these two concepts and thereafter responds to the paradoxes identified in local and international students' understanding of tolerance and respect.

Key words: Human rights literacies, paradoxical understandings, tolerance, respect

\section{INTRODUCTION}

In an article, Intolerance and discrimination (2003), Jürgen Habermas reflects on the pragmatic understanding of the epistemology of tolerance. He positioned and linked the 'historical origin' of tolerance to the $16^{\text {th }}$ and $17^{\text {th }}$ centuries. The justification for the implementation of tolerance was necessary amongst Europe’s diverse religious groups in order to curb religious violence during the Reformation (Habermas 2003, 2). These laws compel the 'majority' (or minority) to 
act and behave within the law (as a legal act of toleration) towards those who have been religiously or otherwise oppressed or persecuted (Habermas 2003, 2).

The original reasons for implementing actions against intolerant behaviour remain important and should be contextualised continuously. Many United Nation declarations, documents and legislations in nation states propose values and actions of living together and social cohesion (UN 1948; South African Bill of Rights 1996). In the calendar of the United Nations, 16th November is annually declared as 'Tolerance Day', with special messages as reminders of the importance of social cohesion and embracing diversity as a vital strength for peace in the world.

Tolerance is much more than passively accepting the 'other'... This means building societies founded on respect for human rights, where fear, distrust and marginalization are supplanted by pluralism, participation and respect for differences (Ban Ki-Moon 2015).

Tolerance as virtue and as action is complex and many scholars theorise on paradoxes and realities underpinning these two notions (Nieto 2002; Carter 2013). It is viewed from different perspectives, for example, religion and law (Habermas 2003), religious tolerance/intolerance, especially in Western democracies (Nussbaum 2012), linking tolerances to political governance (Brown 2006), ethical pluralism and the virtue of being human (Oberdiek 2001) and compatibility and incompatibility of tolerance and respect (Carter 2013). Laws on toleration are partially successful through implementation or internalising liberal values. However, intolerant behaviour seems to be escalating into a worldwide phenomenon, trying to counter the influence of globalisation, liberal democracies, political and social philosophies (Brown 2006, 9). Many global social issues indicate a growing intolerance towards cultures, religions, races or just for being 'the other' (Nussbaum 2012). What were once distant social issues, now need to be dealt with in national boarders or social and local communities.

Respect, on the other hand is perceived as an ideal for diverse multicultural and multiethnic societies (Nieto 2000). Respect is regarded as an important virtue and relational component in social interactions (Carter 2013). De Cremer and Mulder $(2007,443)$ also refer to respect as 'a moral building stone or even gatekeeper for a moral and humanitarian community'. Whilst laws were originally promulgated to impose tolerance and to punish or discipline intolerant behaviour, respect as virtue seems to rely mainly on an individual's or nation’s moral conscience (cf. Schirmer, Weidenstedt and Reich 2012).

\section{TOLERANCE AND RESPECT}

The complexities of the concepts tolerance and respect have been scrutinized by many scholars 
(Nieto 2000; Habermas 2003; Brown 2006; Nussbaum 2003; Carter 2013). Carter (2013, 195) describes specifically compatibility and incompatibility theses on tolerance and respect. He elucidates the complexities and appraisals of these two concepts and highlights their paradoxes and dichotomies either to combat intolerant behaviour or that respect 'superseding or excluding' toleration (ibid.). Carter's (2013) theory further describes the complexities and presents different philosophies linked to liberal democratic, political and educational ideals. His compatibility and incompatibility theses of tolerance and respect are of interest for this article and will be linked to the data and students' feedback in the Human Rights Literacy: Quest for meaning (2012-2015) project.

\section{Tolerance defined}

Habermas $(2003,2)$ describes tolerance in English as a 'form of behaviour' which he argues is 'distinguished from “toleration”, the legal act'. In this instance permission is granted to practice any cultural, religious or social activity. In German semantics, according to Habermas (2003, 3), "the predicate "tolerant" refers to both a legal order that guarantees toleration and to the normative expectation of tolerant behaviours'. He argues further that one can only apply toleration when different parties base their rejection and elimination of discrimination and counter prejudices on cognitive conflict between the beliefs and attitudes. To fight for equal rights does not mean to become more tolerant.

Vogt (1997), Bain-Selbo (2003) and Wilson (2014) argue that tolerance as action and virtue is important to resist and fight discrimination and to counter prejudices. Nieto (2000), on the other hand, critiques the notion that tolerance is the only approach or foundation to understand diversity. How tolerance and respect are applied in social contexts and moral issues questions the support or undoing of these virtues and progressions in society and education (Nieto 2002, 276). Although tolerance needs to support humane actions and behaviours, it does not necessarily promote the internalisation of the values of being tolerant. Schirmer, Weidenstedt and Reich (2012, 1050) argue that one may have more negative connotations to tolerate people who one actually dislikes. This 'objection component' disallows an individual all the freedoms and practices one would or could claim for oneself. Toleration could maintain a state of power imbalances, between those who tolerate and those who are being tolerated. In many instances tolerance is denounced as an obstacle for understanding diversity without contextualising the historical roots of the societies in question (Wilson 2014). The histories of nations, societies, ethnic majorities or minorities, colour the outcome of the nature in which tolerance or tolerant behaviour will feature. 
Nussbaum (2012, 98-100) indicates that in many instances intolerant individuals are not interested in deliberation, self-examination and coherence and their actions and behaviours cannot reflect or adjust to new ways of recognition. Vogt $(1997,3)$ concurs that tolerance has 'the intentional self-restraint in the face of something one dislikes, objects to finding threatening, or otherwise has a negative feeling toward'. Pasamonik $(2004,206)$ added to this notion by arguing that tolerance 'may lose its charm when applied in a specified context. It may be neither a positive value nor a universal or primordial one, even in a liberal society'. It becomes clear that tolerance in social contexts is not only part of political genres which can foster coercive undertones but might develop into actions by those who feel and are excluded. Intolerant behaviour and actions can and will also erupt when voices of social injustices are suppressed and inequalities are overlooked.

\section{Respect defined}

Schirmer, Weidenstedt and Reich $(2012,1057)$ give an extensive explanation on the comprehension of respect and how respect as agency gives meaning to individuals and groups in different social settings. They draw on sociological theories of respect and describe the complexity and multidimensionality of the phenomenon. They suggest that focussing on respect instead can be a more adequate way to interact with ethnic minorities or majorities and 'the other'. Respect has more positive associations with action and re-action and as a virtue, action and agency, it also has the propensity to overcome negative social intersections (ibid.). The individual should not be subjected to tolerance only for being different or because of their social stance or being part of another group. Respect as action can counter feelings of ethnic or racial groups suffering from a feeling and social behaviour as being 'a lower status in society' (Schirmer, Weidenstedt and Reich 2012; Buttny and Williams 2000). If one claims that respect has more agency, it means also better treatment and humane actions towards those who should be respected. This is not only applicable to racism but to all sections of society, culturally, religiously, sexually and politically. Individuals, mostly those in a majority or in a so-called higher social order, take respectful treatment for granted (Buttny and Williams 2000, 111, 121). The inherent significance lies in those, as minorities and/or majorities, to be respected. If groups or individuals have to fight just for being respected, it will contribute to the reasons why tolerance is sustaining and perpetuating its negative connotations in societies. Respect holds not only a virtue status, but becomes a social interaction for all whose welfare is equally important. 


\section{Are toleration and respect paradoxical?}

Toleration and respect are fundamental concepts explained in human rights policy documents and linked to society's actions and behaviour. In his paper Are toleration and respect compatible? Carter (2013) gives a comprehensive outline of the two concepts under discussion and links his arguments to suggested compatible and incompatible theses. He argues that toleration and respect do not necessarily exclude one another and positions the two concepts within liberal democratic virtues (Carter 2013, 195). He acknowledges that there are in both theses 'cases of toleration (that) are never compatible with respect, even if there is no shift in the meaning of respect'.

Carter $(2013,196)$ identifies three structural features of tolerance as: 'an objection component, an acceptance component and a power condition'. The 'objection component' consists of a judgment which involves practical reasoning for removing the presence of the tolerated and restricting power and/or freedom. It means that judgement is served on the object. This objection can appear in many ways, restricting movement, presence, power or anything that will limit the individual's or group's freedom.

The acceptance component excludes objection and contains elements of non-interference. The individual/group does not interfere and one can live one's life as one wishes and equally with others. People are 'respected rather than tolerated' (Carter 2013, 197) and enjoy the freedoms that are allocated to all. The power condition gives the tolerant person 'the power to interfere successfully in the way prescribed by the objection component' (Carter 2013, 196). Power relations are never equal and are part of asymmetric relations between individuals or between state and citizenry. Nussbaum $(2010,440)$ concurs when she reflects on power relations and tolerance stating that '(P)eople behave badly when the human beings over whom they have power are dehumanized and de-universalised’.

The compatible thesis between respect and tolerance, as Carter $(2013,196)$ outlines it, is '... because respect grounds certain rights, and to tolerate a person or belief or practice is to recognise and uphold those rights'. This thesis is grounded in that '... respect provides one plausible justification for the acceptance component of toleration' (ibid., 197). Respect provides a space in which the individual can act as a moral agent and 'the other' is equally recognised as a moral agent. This includes all the capacities like freedom and responsibility and making one's own choices. Although it seems that there is an absence of interference that gives authority, toleration in itself has an objection component. There seems to be a paradox and tension between toleration and respect. Toleration implies that a group or individual's recognition or practice could not have equal rights. Carter $(2013,197)$ states that if the group's or individual's 
recognition does not exist, their political power (being citizens exercising their political agencyauthor) 'ensures their continual existence'. The objection component in tolerance, as outlined before, implies not only intolerance but also disrespect (Carter 2013, 198). One respects the agency, but objects to the choices the agents make. To respect an individual is to recognise their abstract abilities to make judgements. Where the judgements are negative they qualify for the objection component of tolerance. The recognition of respect is to uphold fundamental and equal rights. To respect an individual has a twofold function: the 'recognition of respect' and the appraisal of respect which means showing a positive assessment of the individual. In summary: whilst an individual (as moral agent) upholds equal rights (recognition respect), the content of one's moral character or choices one makes/made may deserve no respect (appraisal respect) (Carter 2013, 199).

Carter $(2013,196)$ describes the core of the incompatible theory on respect and toleration firstly as: '... one cannot both respect something and evaluate it negatively', and secondly that '... respect contradicts the objection component of toleration' (ibid., 197). Commitment is one of the main notions and equality inherently serves as a commitment to individual rights. Equality is linked to equal treatment which gives an entitlement for the individual as morally relevant which deserves respect (Carter 2013, 199). Capacity is also given to the individual to act as moral agent and one respects an individual as moral agent and inherently her/his dignity. ${ }^{1}$ Therefore, one needs to show a certain kind of respect, which is imbedded in the moral status of the individual as equal. Carter $(2013,199)$ calls this kind of respect 'opacity respect'. Opacity respect represents a particular interpretation of recognition respect which underlines equality.

The main argument is to recognise that every individual holds and enjoys agency. Carter $(2013,200)$ argues further that the attitude one adopts when referring to opacity respect means: '... not only to recognise that she(he) possesses certain agential capacities, but is also to turn a blind eye to the degree (above minimum threshold) to which she(he) possesses certain basic capacities'. The latter featuring of a minimum threshold as part of respect suggests not only the recognition of the minimum threshold but also overlooking any particularities or actions, as moral agents, above the minimum threshold. It is important to note that respect serves to justify basic human rights and equality. Carter $(2013,202)$ construes that the incompatible thesis between respect and tolerance is true just to a certain point, and that respect and toleration are incompatible where the 'objection violates opacity respect'. It implies that where negative evaluation of an individual involves assessing, 'basic agential capacities on which their moral personality supervenes and which serves thereby to establish basic equality’ (ibid.) becomes incompatible. Carter, however excludes the evaluation of talents or intelligence as capacities 
that an individual brings to the labour market or to obtain a degree as 'implying an evaluation of basic agential capacities’ (ibid.).

\section{TRIGGERING EXAMPLES DURING \#MUSTFALL PROTESTS FOR REVIEWING THE PROJECT'S CAPTURED DATA (2013 and 2015)}

The 2015/2016 \#MustFall student protests (Booysen 2016) at most public HEI in South Africa, reflected and echoed many students' anger and concerns about the economic disparities, poverty, social injustices, colonial and apartheid past. All these issues are historically rooted in our unequal society. Discussions, debates and visuals in the main stream media reported on students' actions, were sometimes regarded by the discussants as 'intolerance and disrespect towards management, their peers, institutional structures and society-at-large' (Habib in Daily Maverick $5^{\text {th }}$ December 2016).

Two incidents intrigued the reviewing of the two surveys 2013 (Survey2013) and 2015 (Survey2015) and focus group discussions (FGD 2013) on students' understanding of tolerance and respect conveyed during the research project. One can assume that many students who participated in the project's surveys and focus group discussions were also part of the protests. The same student fraternities and universities where protests evolved were participating faculties and universities. The age and academic year of the students also fitted the biographical profiles gathered during the two surveys.

In two examples screened on national television, involved students and management in heated differences. It is not possible to extrapolate students’ actions from a secluded research environment, with online surveys and the comfort of small focus group discussions, where voices and reasoning are equal, to protest conditions in polarised violent environments. However, it is possible to link notions of tolerance and respect to these incidents and question the deeper understanding and type of tolerance and respect observed.

\section{Example one}

During the initial days of the \#MustFall protests (September 2016), an interaction was captured on national television, between a young female student leader and a university's management representative, who was a middle-aged male. Both were members of the same university and met outside the university gates. In the interaction between the two individuals, the anger of the young women was expressed in her shouting and he, in his facial and body language, showed that he was annoyed. She commands the university management representative 'to go and sort out the mess', probably referring to the demands and issues related to the protests. The senior 
person tried to answer the young women, but was not given a chance to respond and he was physically forced to leave the scene.

\section{Example two}

The second example elaborates on the same \#MustFall protests a few weeks later (October 2016). The tension between students and university managements at most public HEI was much fiercer. Many students expressed their anger through more protests, acts of violence and disruption. These aggressive acts were again captured on national television. One incident showed a scene involving a vice-chancellor of a university together with student protesters under the watch-full eye of security personnel. Aggression was expressed by students pushing the individual and shouting derogatory terms at him. The interference of the police and security personnel seemed to be the only option to counter possible violent acts and harm that might occur to any individual.

In both the above-mentioned examples, it became clear that student protesters ridiculed senior officials as their institutions' representatives. The interactions might be labelled as disrespectful behaviour and intolerance towards other individuals. What triggered the reassessment of the captured data of the project was firstly that concepts related to human rights that acknowledge respect and/or tolerance (Survey2013; Survey2015; FGD 2013 ) made way for intolerance, mistrust and anger (Carter 2013, 197; Nussbaum 2012, 100). Secondly, it became clear that these concepts were linked to the different layers of reasons related to students' histories (Wilson 2014; Roux and Becker 2016). The reasons to support the eradication of social injustices, listening to economically deprived and socially excluded students, linking actions to the philosophies of decolonization, could undoubtedly develop into actions of inconsistency which started to differ from what one is supposed to do (Nussbaum 2012). Nussbaum (2012, 100) warns that the 'failure to treat others as full equals ... might lead to arrogance and narcissistic behaviours' and illustrates the complexities of the actions of tolerance and respect in praxis.

\section{STUDENTS' UNDERSTANDING OF TOLERANCE AND RESPECT}

\section{Contextualising the research project}

The aim of the project Human rights literacy: A quest for meaning (2012-2015) was primality to determine the knowledge field of human rights education in teacher education faculties of education at South African universities (Roux and Du Preez 2013). From this understanding, 
the proposed outcome was to develop a theoretical and philosophical underpinning for human rights literacy for teacher education and other curricula. The research concentrated on different specialised areas and tried to contribute to the ontology and epistemology of human rights literacies. The project employed a rhizomatic research design based on grounded theory with different qualitative and quantitative methodologies (Becker, De Wet and Parker 2014).

The research project was conducted in two phases. Phase one, from 2012 to 2014 included seven South African universities sites ${ }^{2}$ in metropolitan and rural settings. Participants (only teacher education students) originated from deep-rural, semi-metropolitan and metropolitan environments. Crystallisation of the data resulted in fascinating outcomes from the first phase, and interest of international collaborators resulted in a second phase (2015) which included students from social sciences (education, law, political sciences and humanities) from 6 countries $^{3}$ at 8 university sites (campuses).

Data gathering in the first phase were concluded in 2013. The qualitative and quantitative methods used were: walk-abouts2013 $(n=80)$, survey2013 $(n=1192$ students accessed the survey and 1086 students completed the survey) and 68 participants in different focus group discussions $\left(\mathrm{FGD}_{2013}\right)$. The unstructured focus groups in face-to-face discussions ${ }^{4}$ were voluntary and were conducted over a short period of time in order to give participants ample time to reflect on the issues. Dialogue and discourses resulting in conflicting ideas were aimed 'at eliciting dialogue about human rights and probing participants' conceptions and ontology and to disrupt fixed meanings and understandings' (Becker, De Wet and Parker 2014, 250). The data gathering in the second phase (2015) included on-line surveys (n=434 students accessed the survey and 351 completed the survey), interviews ( $n=35)$ and an invitation to all participants to reflect via e-mail on selected topics (n=12) (Roux 2016; Roux and Becker 2016). In order to have a clear oversight of all the institutions, a contextual, cultural and institutional mapping of each institution was drawn up by each institutional collaborator of the project (Phase 1 and 2).

Both surveys gathered a mixture of quantitative data by means of structured Likert-scales and multiple-choice questions and qualitative data from a few open-ended questions and optional comment boxes provided (Becker, De Wet and Parker 2014). The first survey (Survey2013) has 74 questions ( $n=1085)$ and was executed in May, 2013. The second survey (Survey2015) consisted of 54 questions ( $\mathrm{n=351)}$ and was executed between May to November, 2015. The number of South African contextual questions in the second survey was reduced. Firstly, it was important to narrate only contexts that all participants can relate to. Secondly, in order to further crystallise gathered data on the epistemologies of human rights literacies and include new concepts. In hindsight, the time and dates when the 2015 survey was executed 
became important because of a number of events unfolding in South Africa and in countries participating in data collection internationally. Specifically, these events were: (i) the violence experienced during the xenophobic attacks in South Africa; (ii) the \#MustFall student protests emerging on South African HEI and campuses; (iii) the migrant and refugee crisis evolving in Europe and the Middle East; and (iv) Israel and India both experienced sporadically domestic violence and border clashes where issues of human rights were regularly reported on. These combinations of social issues and circumstances could have influenced and prompt awareness of students' understandings of human rights concepts. The sections on knowledge acquisitions on human rights in both surveys were used in the analyses to detect with which concepts associated with human rights did students identify and how they clarified these concepts.

\section{Methodology for crystallisation of data}

In this article a hermeneutical interpretation of the data was used in order to reflect on the participants' understanding of concepts of tolerance and respect. The two incidents that triggered a review of the research data on respect and tolerance are contextually bound and linked to histories that might bring clarity to the way in which understanding is taking place (Gadamer 2013; Bontekoe 1996). I draw on Gadamer's elements of hermeneutical experience $(2013,278)$ and an interpretative approach to texts and contexts. This interpretative approach clarified participants' choices in the survey and the discourses of the students' understandings in identifying the paradoxes of the concepts under discussion. It was vital to link the participants' knowledge and understanding of these human rights concepts (words, texts and voices) to their respective contextual, social and cultural mappings. Acknowledging their inputs and the meanings of their understandings could not be understood in an arbitrary way. Listening and reading, the initial meanings emerged from texts and students' voices (gathered in surveys and focus group discussions). This exercise interpreted the use of language/meaning 'as the determination of the hermeneutic act' (Gadamer 2013, 414). Gadamer $(2013,281)$ argues that '(J)ust as we cannot continually misunderstand the use of the word without its affecting the meaning of the whole, so we cannot stick blindly to our own fore-meaning about the thing if we want to understand the meaning of another'. Gadamer $(2013,416)$ argues that '(N)ot only is the special object of understanding, namely tradition, of a verbal nature: understanding itself has a fundamental connection with language' and he refers to this notion also as a 'concretion of the meaning itself' (ibid.). The recognition of the influences of prejudice, which are also influenced by historical circumstances, made it more complex to link the interpretative approach to critical analyses of the voices in the texts and the voices on the texts. This link to 
the texts and the languages of the participants, can develop into dissonance mirrored against the cultural mapping of the individual (Becker 2013). This includes understandings and actions that tolerance and respect might have on relations between individuals and groups.

\section{Exploring the data on tolerance and respect}

The questions to be asked are: What are the complexities in understanding the concepts of tolerance and respect? and How do these complex and paradoxical understandings of tolerance and respect infuse praxis?

\section{Examples from the surveys}

Two questions in both surveys Question 13 (Survey2013) and Question 18 (Survey2015) were directed to prioritising concepts relating to human rights. More options were given in Survey2013 than the reduced options in Survey2015. The reason for choosing fewer options in Survey2015 was to use concepts applicable to international documents only and within the realm of all participants. Tolerance as concept did not feature in the first survey (Survey2013) but was included in the second survey (Survey2015).

\section{Question 13: Please select any 10 of the following words or phrases you associate most with human rights (Survey2013)}

Forty-five different concepts and words were given ${ }^{5}$ and $(n=1058 / 1085)$ students answered the question. Due to the different contexts of the universities there was a possibility that not all students were familiar with human rights issues or have access to human rights documents either in their courses or in the social contexts of the different campuses. The first six important concepts students associated with human rights were the following:

Table 1: Concepts related to human rights (2013)

\begin{tabular}{|c|c|l|}
\hline Number of hits & Percentage & \multicolumn{1}{|c|}{ Concept/word } \\
\hline 793 & 74.86 & Freedom \\
\hline 760 & 71.83 & Equity \\
\hline 652 & 61.63 & Respect \\
\hline 549 & 51.89 & Protection \\
\hline 431 & 40.74 & Social Justice \\
\hline 430 & 40.64 & Dignity \\
\hline
\end{tabular}

Students related to human rights as (i) freedom (ii) equity (iii) respect (iv) protection (v) social justice and (vi) dignity. Taking the histories of South African students into consideration, 
students should have been more aware of discrimination, disrespect and intolerance behaviours and experiences imbedded in racism and sexism (Wilson 2014; Roux and Becker 2016). It was interesting to note that respect as concept was not prioritised in relation to concepts such as freedom. These concepts are all part of the vocabulary of most documents on human rights issues (South African Bill of Rights, 1997; United Nations Declaration on Human Rights Education and Training, March 2011; Proclamation of the United Nations Decade for Human Rights Education (1995-2004), Resolution, 49/184). The fact that students regarded freedom and equity as the most important concepts might be linked to political rhetoric on political freedoms and equity in South Africa. Notions and discourses on what respect and social justice entail were further crystallised in the focus groups' discussions.

\section{Question 18. Please select 7 of the following words or phrases you associate with the values of human rights (Survey2015)}

Thirteen concepts and words were given ${ }^{6}$ and $(n=351 / 197)$ students answered the question. Not all students were familiar with human rights concepts although events reporting on human tragedies taking place in Europe and the Middle East were covered by the international media. Table 2 indicated a breakdown of the students' feedback.

In the analyses of all participants' contributions ( $n=351 / 197)$, the four important concepts chosen were: (i) freedom (ii) respect (iii) social justice (iv) tolerance. In the breakdown of the data the participants of the different countries indicate a clear link to their contexts and contextual languages and voices on human rights. The Norwegian and South African student(s) indicated 'respect' as first choice. Taking the contextual histories of the South African students into consideration they were giving voice to the importance of being respected as individuals. This is different from Survey 2013 (Survey2013) where ‘freedom' was indicated. This shift might be linked to many South Africans and students' reflections on racist remarks (since January 2015) on social media on social justice issues and reflecting their experiences and voices against marginalisation in higher education (Roux and Becker 2016). Students from India identified 'social justice' as important and could be linked to social, religious and cultural structures challenged in society. The concept 'freedom' was indicated as the most important concept linked to human rights in Germany, the Netherlands and Israel. Taking the contextual issues and circumstances of the refugee crisis in the midst of two countries in Europe, students and the citizenry were highly aware of 'freedom' and 'tolerance'. Israel was/is coping with political and religious conflicts and in students' reflections in small focus groups (FGD 2015 IL) ${ }^{7}$ 'religious freedom' was the most important issue that they discussed. In most other cases respect or tolerance were regarded as the second important concepts related to human rights. 
Table 2: Concepts related to human rights (2015)

\begin{tabular}{|c|c|c|c|c|c|}
\hline $\begin{array}{c}\text { Number of hits } \\
\text { All participants } \\
n=351 / 197\end{array}$ & Percentage & Concept/word & & & \\
\hline 280 & 88.61 & Freedom & & & \\
\hline 278 & 87.03 & Respect & & & \\
\hline 258 & 81.65 & Social Justice & & & \\
\hline 158 & 50.00 & Tolerance & & & \\
\hline $\begin{array}{c}\text { Number of hits } \\
\text { GERMANY } \\
n=23 / 25\end{array}$ & Percentage & Concept/word & $\begin{array}{c}\text { Number of hits } \\
\text { INDIA } \\
n=74 / 84\end{array}$ & Percentage & Concept/word \\
\hline 21 & 91.30 & Freedom & 70 & 94.59 & Social Justice \\
\hline 20 & 86.96 & Tolerance & 69 & 93.24 & Freedom \\
\hline 20 & 86.96 & Social Justice & 60 & 81.08 & Dignity \\
\hline 17 & 73.91 & Respect & 55 & 74.32 & Respect \\
\hline $\begin{array}{c}\text { Number of hits } \\
\text { NETHERLANDS } \\
n=45 / 43\end{array}$ & Percentage & Concept/word & $\begin{array}{c}\text { Number of hits } \\
\text { ISRAEL } \\
n=60 / 52\end{array}$ & Percentage & Concept/word \\
\hline 40 & 95.24 & Freedom & 47 & 90.38 & Freedom \\
\hline 39 & 92.86 & Respect & 43 & 2.69 & Respect \\
\hline 39 & 92.86 & Protection & 41 & 78.85 & Protection \\
\hline 28 & 66.67 & Social Justice & 38 & 73.08 & Social Justice \\
\hline $\begin{array}{c}\text { Number of hits } \\
\text { NORWAY } \\
n=1 / 1\end{array}$ & Percentage & Concept/word & $\begin{array}{c}\text { Number of hits } \\
\text { SOUTH AFRICA } \\
n=136 / 124\end{array}$ & Percentage & Concept/word \\
\hline 1 & 100.00 & Respect & 120 & 96.77 & Respect \\
\hline 1 & 100.00 & Responsibility & 102 & 82.25 & Freedom \\
\hline 1 & 100.00 & Protection & 101 & 79.84 & Responsibility \\
\hline 1 & 100.00 & Social Justice & 99 & 73.39 & Fairness \\
\hline
\end{tabular}

\section{Exploring respect and tolerance in the focus groups' discussions}

Although tolerance as concept was not included in question 13 in the survey (Survey2013), the concept was frequently used in the focus group discussions. In an analysis of the transcriptions of the focus group interviews (FGD 2013 ), crystallising students' understandings of respect and tolerance, they indicated two conditions of how respect should be interpreted: (i) respect related to their rural/suburban histories and their upbringing, (ii) conditions of why and who should be respected (Carter 2013).

Three verbatim examples illustrating these conditions are: 
i. Site 1 (metropolitan multicultural university with students from rural suburban and innercity environments)

\section{- $\quad$ Respect related to their histories rural/suburban and upbringing}

People in the rural areas are still living at the time the life as they lived back in the days now so us as the new generation we grew up in the cities and in urban areas so we grew up adapting other countries and other races and styles I would say so ja in rural areas there's still very much respectful of other people. They are still exercising the Ubuntu ${ }^{8}$ thing. In urban areas it is very bad. Very bad (FGD $\left.2013 \_S 1 Y 1 M 1 a P 1 F 1\right)$.

ii. $\quad$ Site 4 (semi-rural multicultural university with a dominant language group. Students comes from cities, suburban, rural and deep rural areas.)

I think it is the way you are brought up, the way your parents taught you how to respect. I think any law can be broken down to respect .... You can bring anything down to respect. I think, it is something that is taught to you by your parents. And it should be from when you are little, because the moment you are in high school, it is too late, because that person hasn't learned to respect others (FGD 2013 S4Y1M1P1M1).

Respect for elders and senior citizens in rural and small town communities is still important due to the histories and hierarchal community arrangements. Students from different races, language and cultural groups support this notion of respect. The second quote indicates that respect is a virtue or gatekeeper for the humanitarian community (De Cremer and Mulder 2007, 443). 'Ubuntu' as African philosophy underpins this student's remark but only linked to rural communities and not to her urban/metropolitan environment. This give an indication that respect, as she reflected it, is not necessary a virtue applicable to all spaces.

iii. Site 1 (Metropolitan multicultural university with students from rural, suburban and innercity environments)

\section{Conditions why and who should be respected}

\section{- Precondition}

I think when you talk about respect it is when you respect the human dignity of someone ... You can't respect a street kid although he or she deserve your respect. You can't just give respect ... If you do something you deserve respect. But I cannot give a street kid respect. I will say is all about the human dignity and respecting ... Myself and respecting each other (FGD 2013_S1Y1M1aP2M1).

This verbatim quote supports aspects of Carter's $(2013,202)$ incompatible thesis that commitment to individual rights is not upheld. Although the student refers to human dignity: the street child's position in society, their living conditions become the precondition for respect. The judgment and objection play into removing the presence of the child and restricting their power and freedom. 


\section{- Unconditional acceptance}

They say you respect those who respects you but I disagree with that because I give you respect and you don't give me respect but tomorrow you will expect me to give respect again even if you did not give me respect today so there is that thing in respecting each other because you may put me down today - you don't give me respect but I will still respect you. So it's just like that (FGD $\left.2013 \_S 1 Y 1 M 1 a P 2 M 1\right)$.

These quotes corroborate the compatible thesis of Carter $(2013,197)$ and includes acceptance that excludes any objection and gives space to the individual as moral agent who enjoys recognition and acceptance. This acceptance excludes objection and contains elements of noninterference (Carter 2013, 197) and sets the ideal for diverse multicultural and multi-ethnic societies (Nieto 2000, 276). This type of respect is an example of opacity respect (Carter 2013, 199). It provides a space in which the threshold given to the individual who should be respected, the liberty to raise the threshold.

\section{CONCLUSION}

The protests of the South African students brought a polyphony of voices as opposed to a monologic voice to their cause. South African students partaking in the research in 2013 and 2015 were possibly also involved in the student protests and violence. In the survey students prioritised human rights concepts that they deemed as important: freedom, equity, respect and social justice (Survey2013; Survey2015). These concepts are in line with their cause and slogans. The 'born free' generation, developed a new language (words, meanings and actions) in their knowledges and understandings of human rights and human rights literacies (Roux and Becker 2016). Part of their new language in understanding human rights is framed in their consciousness of social injustices and internalisation of values of human rights. The notions of respect and tolerance as virtue and as action are linked to social issues and hermeneutical discourses and are all deep rooted in political and social histories and contextualized local content.

Tolerance and respect, and how it plays out in students' actions seemed to be more paradoxical than compatible. Students' taught experiences on respect are linked to their histories and upbringing and are related to their voices in the text (FGD 2013$)$. Their expectations and lived experiences (actions) in trying to develop a new language on social issues, do not relate to their taught experiences and are not related to their voices in the text. The two examples of the students' protests are related and question the consequences and understanding of opacity respect (Carter 2013, 199). The complexity of students' voices and the way they acted might be their reassurance that their voices will be heard and respected. However, respect is more than 
dialogue and the kind of respect given to individuals can undermine the notion of equality (Adami 2013; Carter 2013). One cannot deliberately decide to respect or tolerate. Toleration has in itself power and objection capacities (Carter 2013). If one opts to respect rather than to tolerate, the recognition of the other being either management or students as equals should be linked to opacity respect. This means that all the stakeholders should recognise the agential capacities and accept that particularities or actions can rise above the minimum threshold (Carter 2013, 199-200). This responsibility to be respected will then be applicable to all involved in interactions and discourses.

\section{ACKNOWLEDGEMENT}

This work is based on a research project supported by the National Research Foundation (NRF) of South Africa (Grant Number 81785) 2012-2015. The grant holder Prof Cornelia Roux acknowledges that opinions, findings and conclusions or recommendations expressed in any publication generated by the NRF-supported research are those of the author(s), as members or collaborators of the project, and that the NRF accepts no liability whatsoever in this regard.

\section{NOTES}

1. Carter $(2013,202)$ explains his position on dignity not as the Kantian dignity where 'dignity cannot be removed without destroying a person, neither can it conferred by others'. Carter holds the position that there is another kind of dignity as 'that can be both removed and conferred, both by the person herself and by others ...'. He refers to this kind of dignity 'outward dignity'. Carter (2013, 201) describes it as ' ... involving a kind of concealment, an immunity to exposure'. For the purpose of this article I will not reflect on this notion but concentrate on the types of respect underlying the incompatible thesis.

2. One university site withdrew at the end of 2012.

3. The six countries that took part in the survey were South Africa (two universities); Germany; India; The Netherlands; Israel and Norway. The aim was to include student participants from different cultural, religious economic and social environments. Students were enrolled at Faculties of Education, Humanities and Law

4. Referencing the data means Survey ${ }_{2013}$ data was captured in 2013 in South Africa; Survey Comments was (for example SurveyCommentQ31) for open-ended responses in the questionnaire and FocusGroup Discussions_2013 for data emanating from focus-group discussions. Focusgroup references indicate the site, year group, meeting, gender and number of participant (F/M)(1). Example: S1Y4M2 refers to data from a focus group at Site 1(S1), fourth years (Y4) second meeting $(\mathrm{M} 2)$ gender $\mathrm{f} / \mathrm{m} /$ number $=(\mathrm{F} 3) . \mathrm{FGD}_{2013} \mathrm{~S} 1 \mathrm{Y} 1 \mathrm{M} 1 \mathrm{~F} 3$

5. forgiveness; revolution; dignity; against my culture; against my religion; caring; children's rights; controversial; code of conduct; courts; constitution; education; employment; entitlement; equality; expression; fairness; freedom; humanism; legal; law; liberal; morality; not realistic; oppression; police; politics; protection; punishment; promises; respect; regulate; rules; relationships; sacrifice; selfishness; social justice; treating others well; unbiblical; unfair; united nations; women's' rights; religion; do onto others as you would have. 
6. freedom; respect; social justice; protection; responsibility; fairness; dignity; tolerance; morality; caring; relationship; entitlement; selfishness.

7. For the purpose of this article international focus group discussions are not included.

8. Ubuntu is part of the African philosophy and virtues as 'I am because you are'.

\section{REFERENCES}

Adami, R. 2013. Intersectional dialogue - A cosmopolitical dialogue of ethics. Stockholm University Cosmopolitan Civil Societies Journal 5(2) 45: 1837-5391. http://utsescholarship.lib.uts.edu.au/ epress/journals/index.php/mcs

Bain-Selbo, E. 2003. Mediating the cultural wars. New Jersey: Hampton Press.

Ban Ki-Moon 2015 International day for tolerance. http://www.un.org/en/events/toleranceday (accessed 10 October 2016).

Becker, A., A. de Wet and G. Parker. 2014. Moving towards understanding one another: Cornelia Roux on religion, culture and human rights. Journal for the Study of Religion 27(1): 234-266.

Becker, J. A. 2013. Curriculum and intra-dialogical spaces: Consciousness and becoming in identity construction based on human rights values. Unpublished PhD. Faculty of Education Sciences, North-West University, South Africa.

Bontekoe, R. 1996. Dimensions of the hermeneutical circle. New Jersey: Humanities Press.

Booysen, S. 2016. Two weeks in October: Changing governance in South Africa. In Student revolt, decolonialisation and governance in South Africa Fees must fall, ed. S. Booysen, 22-52 Johannesburg: Wits University Press.

Brown, W. 2006. Regulating aversion: Tolerance in the age of identity and empire. New Jersey: Princeton University Press.

Buttny, R. and P. L. Williams. 2000. Demanding respect: The uses of reported speech in discursive constructions of interracial contact. Discourse and Society 11(1): 109-133.

Carter, I. 2013. Are toleration and respect compatible? Journal of Applied Philosophy 30(3): 195-208.

De Cremer, D. and L. B. Mulder. 2007. A passion for respect: On understanding the role of human needs and morality. Gruppendynamik und Organisationsberatung 38(4): 439-449.

Gadamer, H. G. 2013. Truth and method. 2013 ed. London: Bloomsbury.

Habermas, J. 2003. Intolerance and discrimination. International Journal of Constitutional Law 1(1): $2-12$.

Habib, A. 2016. The politics of spectacle-reflections on the 2016 student protest. Daily Maverick, 5 December 2016. https://www.dailymaverick.co.za/article/2016-12-05-op-ed-the-politics-ofspectacle-reflections-on-the-2016-student-protests/\#.WGEcXlxVfqU (accessed 26 December 2016).

Ivanhoe, P. J. 2009. Pluralism, tolerance and promiscuity. Journal of Religious Ethics 37(2): 311-329.

Nieto, S. 2000. Affirming diversity. $4^{\text {th }}$ Edition. New York: Longman.

Nussbaum, M. C. 2012. The new religious intolerance in Europe. Boston. Harvard University Press.

Oberdiek, H. 2001. Tolerance. Between forbearance and acceptance. Lanham: Rowman and Littlefield.

Pasamonik, B. 2004. The paradoxes of tolerance. Social Studies 95(5): 206-210.

Roux, C. and A. Becker. 2016. Humanising higher education in South Africa through dialogue as praxis. Educational Research for Social Change 5(1): 131-143.

Roux, C. and P. du Preez. 2013. Human rights literacy: A quest for meaning. http://hrlit.org/documents (accessed 15 January 2015).

Roux, C. 2016. Interlocutors, human rights education and interreligious dialogue: A South African 
perspective. In Human rights and religion in educational contexts, ed. Manfred Priner, Johann Lähnemann and Heiner Bielefeldt, 307-321. Switzerland: Springer.

Schirmer, W., L. Weidenstedt and W. Reich. 2012. From tolerance to respect in inter-ethnic contexts. Journal of Ethnic and Migration Studies 38(7): 1049-1065.

South African Bill of Rights. 1996. Chapter 2 of the Constitution of the Republic of South Africa. www.info.gov.za/documents/constitution/1996/96cons2.htm (accessed 22 July 2009).

UN see United Nations.

United Nations. 1948. Universal declarations on human rights. General Assembly resolution 217A. http://www.ohchr.org/en/udhr/pages/introduction.aspx (accessed 22 October 2016).

United Nations Academic Impact. 2015. Sharing a culture of intellectual social responsibility. https://academicimpact.un.org/content/international-day-tolerance-16-november (accessed 16 October 2016).

United Nations Declaration on Human Rights Education and Training. 2011. http://www.ohchr.org/EN/ Issues/Education/Training/Pages/UNDHREducationTraining.aspx (accessed 22 October 2016).

United Nations Decade for Human Rights Education. 1995-2004. Resolution, 49/184. http://www.ohchr.org/EN/Issues/Education/Training/Pages/Decade.aspx (accessed 22 October 2016).

Vogt, W. P. 1997. Tolerance and education: Learning to live with diversity and difference. Thousand Oaks. CA: Sage.

Wilson, H. F. 2014. The possibilities of tolerance: Intercultural dialogue in a multicultural Europa. Environment and Planning D: Society and Space 32: 852-868. 